\title{
REORIENTASI KEUTAMAAN ILMU DALAM \\ PENDIDIKAN PERSPEKTIF AL-GHAZALI PADA KITAB IHYA 'ULUMUDDIN
}

\author{
Agus Setiawan \\ Dosen IAIN Samarinda, Kalimantan Timur, Indonesia \\ agus.rdat@gmail.com
}

\begin{abstract}
Abstrak
Bahwa problem yang terbesar di kalangan umat manusia saat ini adalah acuh terhadap ilmu agamanya. Faktanya terkadang ilmu agama dinomor duakan sedangkan yang nomor satu adalah ilmu umum. Bahkan sekarang yang menjadi panutan adalah media sosial, bukan ilmu yang dipelajari. Pada tataran di Indoneia idealnya pendidikan memberikan andil besar dalam memberi solusi terhadap krisis kemanusiaan yang kini melanda kehidupan. Mulai pendidikan, kita ingin menghasilkan manusia yang jujur, bersemangat, pekerja keras, tidak malas, berani, kreatif, cinta kebersihan, toleran dan sebaginya.Oleh karena itu sangat sayang sekali kalau sebuah karya yaitu Ihya 'Ulumuddin karya al-Ghazali tidak di implementasi. Karya tersebut tidak melulu membahas satu bahasan keilmuan saja namun berbagai ilmu terkadang dibahas dalam satu kitab. Semisal Ihya' Ulumuddin. Dalam kitab tersebut membahas tentang konsep ilmu, konsep Aqidah, fiqh dan lainnya. Hal ini mengindikasikan bahwa al-Ghazali adalah seorang representatif ulama' integral dengan keilmuannya dan sangat relevan untuk diimplementasikan saat ini. AlGhazali menyebutkan bahwa untuk meraih kebahagiaan negeri akhirat hanya bisa dicapai melalui penguasaan terhadap ilmu mengenai akhirat. Semua itu semakin menguatkan posisi ilmu, ketetapan tentangnya, dan kedudukan mulia mereka yang memiliki ilmu dalam pandangan Allah SWT. Manusia yang memiliki ilmu dikatakan oleh al-Ghazali dapat memperoleh derajat atau kedudukan paling terhormat di antara sekian banyak makhluk di permukaan bumi dan langit karena ilmu dan amalnya.

Keywords : Keutamaan Ilmu, Perspekstif Al-Ghazali, Kitab Ihya 'Ulumuddin
\end{abstract}

\section{A. Biografi Singkat Al-Ghazali}

Al-Ghazali adalah seorang genius dan sumbangannya kepada pemikiran muslim terletak pada penemuannya mengenai batas-batas yang terdapat dalam akal pikiran seseorang sebagai alat dari pengetahuannya dan pusat terpenting dari hati sebagai tempat berpijak dari seluruh

Jurnal Ilmiah Al QALAM, Vol. 12, No. 1, Januari-Juni 2018 
Agus Setiawan: Reorientasi Keutamaan Ilmu Dalam Pendidikan Perspektif Al-Ghazali Pada Kitab Ihya 'Ulumuddin

pengetahuan dan pengalaman. ${ }^{1}$ Beliau lahir pada abad $5 \mathrm{H}$ sebagai ilmuan dari pemikir Islam yang masyhur pada zamannya yaitu pada zaman Abbasiyah. Diantara tokoh terkenal pada waktu itu seperti: al-Syahrastani, al-Ragib al-Asfihany, Umar Khayam, Nizham al-Mulk, al-Hariry dan lainlain. $^{2}$

Beliau mempunyai nama lengkap Abu Hamid Muhammad bin Muhammad al-Thusi al-Ghazali, ${ }^{3}$ dan lebih dikenal dengan sebutan alGhazali. Namanya kadang diucapkan Ghazzali (dua z), artinya tukang pintal benang, karena pekerjaan ayah al-Ghazali ialah tukang pintal benang wol. Sedangkan yang lazim ialah Ghazali (satu z), ${ }^{4}$ disebut demikian karena beliau dilahirkan di Ghazalah, di kota Thus termasuk daerah Khusaran Iran pada tahun 450 H/1058 M. Al-Ghazali mendapat gelar panggilan Imam besar Abu Hamid al-Ghazali Hujjat al-Islam ${ }^{5}$ Zainuddin dan dikenal juga Muhammad bin Muhammad bin Muhammad al-Ghazali al-Thusi al-Naisabari, al-Faqih, al-Shufi, al-Syafi'i, al-Asy’ari. ${ }^{6}$

${ }^{1}$ Ali Issa Othman, Manusia Menurut Al-Ghazali, (Bandung: Pustaka, 1987), h. 15.

${ }^{2}$ Asrorun Ni'am Sholeh, Reorientasi Pendidikan Islam Mengurai Relevansi Konsep Al-Ghazali dalam Kontek Kekinian, (Jakarta: eLSAS, 2004), h. 9.

${ }^{3}$ Tim Dosen Fakultas Tarbiyah UIN Malang, Pendidikan Islam dari Paradigma Klasik Hingga Kontemporer, (Malang: UIN-Malang Prees, 2009), h.161.

${ }^{4}$ Abidin Ibnu Rusn, Pemikiran Al-Ghazali tentang Pendidikan, (Yogyakarta: Pustaka Pelajar, 2009), h. 9.

${ }^{5}$ Selain dikenal sebagai Hujjatul Islam beliau juga dikenal sebagai Bahrun Mughriq (laut yang menenggelamkan) oleh gurunya sendiri hal tersebut karena kecerdasannya dan kemampuannya, bahkan ada yang menyebut bahwa al-Ghazali merupakan pemikir besar Islam yang kontribusi pemikirannya banyak diadopsi oleh kaum muslimin khususnya dan orang-orang Barat umumnya. Lihat Marzuki, dkk, dalam Wacana Jurnal Studi Islam, (Surabaya: IAIN Sunan Ampel, 2005), h. 13, lihat juga Abu Muhammad Iqbal, Konsep Pemikiran Al-Ghazali tentang Pendidikan, (Madiun: Jaya Star Nine, 2013), h. 3.

${ }^{6}$ M. Ladzi Safroni, Al-Ghazali Berbicara tentang Pendidikan Islam, (Malang: Aditya Media Publishing, 2013), h. 11.

Jurnal Ilmiah Al QALAM, Vol. 12, No. 1, Januari-Juni 2018 
Agus Setiawan: Reorientasi Keutamaan Ilmu Dalam Pendidikan Perspektif Al-Ghazali Pada Kitab Ihya 'Ulumuddin

Al-Ghazali adalah anak tertua dari dua bersaudara. Adik al-Ghazali bernama Ahmad, kemudian diberi gelar "Abul Futuh: dia juga seorang juru dakwah yang tersohor yang diberi julukan "Mujiduddin". 7

Ketika kedua saudara itu masih kecil, ayahnya meninggal dunia.Ayahnya meskipun seorang tukang pintal benang dan berpenghasilan kecil, tetapi memiliki kecintaan pada ilmu dan harapan yang besar pada anak-anaknya. Itu sebabnya pada saat meninggal dunia, ia menitipkan anak-anaknya pada seorang sahabat untuk dididik. Kemudian oleh sahabatnya ini, anak-anak itu di sekolahkan pada sekolahan yang menyediakan biaya bagi murid-muridnya. ${ }^{8}$

Pada masa itu memang terdapat kemudahan bagi pendidikan rakyat biasa. Tersedia berbagai sarana pendidikan cuma-cuma untuk umum. Banyak lembaga swasta pada masa itu dipimpin oleh para ilmuan. Biaya pendidikan, termasuk biaya hidup, ditanggung oleh pemuka setempat. Orang yang termiskin pun pada waktu itu mendapatkan kesempatan yang sama untuk memperoleh pendidikan tertinggi. Maka muncullah dari lapisan masyarakat terbawah para cendekiawan raksasa, seperti Abu Hanifah pedagang kecil kain, Syamsul Aima penjual manisan, Abu Ja'far pembuat peti mati dan Allam Kaffal Mozari seorang pandai besi. ${ }^{9}$

Kesempatan emas ini dimanfaatkan oleh al-Ghazali untuk memperoleh pendidikan setinggi-tingginya. Mula-mula ia belajar agama, sebagai pendidikan dasar, kepada seorang ustad setempat, Ahmad bin Muhammad Razkafi. Kemudian al-Ghazali pergi ke Jurjan dan menjadi santri Abu Nasr Ismaili. Setelah menamatkan studi di Thus dan Jurjan, alGhazali melanjutkan dan meningkatkan pendidikannya di Naisabur, dan ia

\footnotetext{
${ }^{7}$ Imam Munawir, Mengenal Pribadi 30 Pendekar dan Pemikir Islam dari Masa Ke Masa, (Surabaya: PT. Bina Ilmu Offset, 2006), h. 338.

${ }^{8}$ Abu Muhammad Iqbal, Konsep..., h. 2.

${ }^{9}$ M. Amin Syukur, Studi Akhlak, (Semarang: Walisongo Press, 2010), h. 46-47.

Jurnal Ilmiah Al QALAM, Vol. 12, No. 1, Januari-Juni 2018
} 
Agus Setiawan: Reorientasi Keutamaan Ilmu Dalam Pendidikan Perspektif Al-Ghazali Pada Kitab Ihya 'Ulumuddin

bermukim di sana. ${ }^{10}$ Di sini ia belajar kepada seorang ulama besar AlJuwaini yang dikenal dengan al-Haramain tentang berbagai keilmuan seperti ilmu kalam, ilmu mantiq dan sebagainya.

Selajutnya ia pindah ke Baghdad, kota pusat kebudayaan dan pengetahuan Islam pada masa itu. Ia mulai mengamalkan dan mengajarkan pengetahuannya sehingga ia berhasil menjadi seorang yang masyhur. Karena kebesaran pribadi dan tingginya pengetahuan, beliau diangkat oleh perdana menteri Nidham al-Muluk menjadi Maha Guru pada Universitas Nidhamiyah pada tahun $483 \mathrm{H} / 1090 \mathrm{M}$, pada usia 30 tahun. ${ }^{11}$ Saat itulah masa kesuksesan karir al-Ghazali, jadi pengaruhnya sangat besar bagi para pembesar dari Dinasti bani Saljuk yang berkuasa pada saat itu. Hampir tidak ada kebijakan dalam bidang pendidikan, politik, budaya dan agama tanpa persetujuan dirinya. Posisinya sebagai pejabat tinggi dan kemashuran namanya sering menimbulkan pertentangan batin, antara kecintaan pada harta, kehormatan, jabatan dan kemewahan dengan suara hatinya untuk tetap berada dalam kesalehan. Berarti dapat dipahami ketika al-Ghazali menulis risalah Ayyuha al-Walad, terdapat salah satu ungkapannya yang menyatakan untuk menghindari pemberian para penguasa, ada unsur politis, mungkin karena kecewa dengan pemerintahan pada waktu itu atau karena secara kejiwaan bertentangan dengan dirinya ${ }^{12}$

Al-Ghazali akhirnya muak dengan segala kepalsuan semua itu. ${ }^{13} \mathrm{Al}-$ Ghazali kemudian memutuskan untuk mengubah arah dan orientasi kehidupannya pada dunia tasawuf. Dengan penuh ketabahan, tahun $488 \mathrm{H}$ ia pergi dari kota Baghdad, meninggalkan segala kemewahan, jabatan, untuk tinggal di Damsyik sampai sebelas tahun lamanya untuk merenung dan memperdalam ilmu dan ibadahnya. Di Damsyik ia melakukan

${ }^{10}$ Jamil Ahmad, Seratus Muslim Terkemuka, (Jakarta: Pustaka Firdaus, 1987), h. 97.

\footnotetext{
${ }^{11}$ Abu Muhammad Iqbal, Konsep..., h.340.

${ }^{12}$ Abidin Ibnu Rusn, Pemikiran..., h.10.

${ }^{13}$ Jamil Ahmad, Seratus..., h. 98.
}

Jurnal Ilmiah Al QALAM, Vol. 12, No. 1, Januari-Juni 2018 
Agus Setiawan: Reorientasi Keutamaan Ilmu Dalam Pendidikan Perspektif Al-Ghazali Pada Kitab Ihya 'Ulumuddin

pertaubatan dengan berkhalwat, beri'tikaf, menyucikan diri dan jiwanya, membersihkan akhlak dan budi pekertinya serta selalu berfikir kehadirat Allah. Perjalanan spiritualnya dilanjutkan ke Darussalam untuk menetap dan berkhalwat di Masjid Baitul Maqdis, kemudian pergi ke Mesir, dilanjutkan ke Makkah dan Madinah untuk menunaikan ibadah haji. ${ }^{14}$

Setelah meninggalkan Hijaz ia menjelajahi Alexandria dan Mesir. al-Ghazali mengembara lebih dari sepuluh tahun, mengunjungi tempattempat suci yang bertebaran di daerah Islam yang luas. Menurut Ibn-ulAsir selama perjalanan itu al-Ghazali menulis Ihya-ul-Ulumuddin, karya utamanya yang mempengaruhi dan sangat mempengaruhi pandangan sosial dan religius Islam dalam berbagai segi.Doa dan ketaatannya kepada Tuhan yang menyucikan hatinya dan mengungkapkan rahasia besar yang sampai saat itu belum diketahuinya.

Tidak lama setelah Fakhrul Mulk mati terbunuh pada tahun 500 H/1107 M, al-Ghazali kembali ke tempat asalnya Thus. Ia menghabiskan sisa umurnya untuk membaca Alqurandan hadits serta mengajar. Di samping rumahnya, didirikan madrasah untuk para santri yang mengaji dan sebagai tempat berkhalwat bagi para sufi. Pada hari Senin tanggal 14 Jumaditsaniyah 505 H/18 Desember 1111 M, al-Ghazali pulang ke hadirat Allah dalam usia 55 tahun, dan di makamkan di sebelah tempat khalwat (Khanaqah)-nya. ${ }^{15}$

Dengan senyum simpul al-Ghazali meninggalkan dunia fana ini.Dan sebagai ucapan filosuf Inggris Francis Bacon yang dikutip oleh Imam Munawwir, dia berhak mengucapkan sepatah wasiat "Aku persembahkan jiwaku ke haribaan Tuhan, dan dikuburkan jasad kasarku ke dalam kegelapan kuburan, tetapi namaku akan tetap hidup dari generasi ke generasi dan akan mengembakan sayapnya ke seluruh umat manusia". ${ }^{16}$

\footnotetext{
${ }^{14}$ M. Amin Syukur, Studi..., h. 48.

${ }^{15}$ Abidin Ibnu Rusn, Pemikiran..., h. 12-13.

${ }^{16}$ Imam Munawir, Mengenal..., h. 350.
}

Jurnal Ilmiah Al QALAM, Vol. 12, No. 1, Januari-Juni 2018 
Agus Setiawan: Reorientasi Keutamaan Ilmu Dalam Pendidikan Perspektif Al-Ghazali Pada Kitab Ihya 'Ulumuddin

Bertolak dari perjalanan hidupnya, lebih dari 300 karya al-Ghazali meliputi berbagai ilmu pengetahuan, diantaranya yaitu Ayyuhal walad ${ }^{17}$ dan Ihya 'Ulumuddin dll. A1-Ghazali adalah seorang pemikir Islam yang sangat produktif, umumya yang tidak begitu lama, yakni sekitar 55 tahun dia gunakan untuk berjuang di tengah-tengah masyarakat dan mengarang berbagai karya ilmiah yang sangat terkenal di seluruh penjuru dunia (Barat dan Timur), sampai-sampai para oreintalis Barat pun juga mengadopsi pemikiran-pemikirannya. Puluhan karya ilmiah yang ditulisnya meliputi berbagai disiplin keilmuan, mulai filsafat, politik, kalam, fiqih, ushul fiqih, tafsir, tasawuf, pendidikan dan lain sebagainya.

\section{B. Mengenal Kitab Ihya 'Ulumuddin}

Di dalam memahami suatu ilmu atau menulis suatu kitab, al-Ghazali mendasarkan pemikirannya pada ajaran-ajaran agama Islam, oleh karena itu sebagian ahli mengatakan bahwa epistemologi yang digunakan oleh alGhazali adalah epistemologi Islam. ${ }^{18}$ Kitab Ihya 'Ulumuddin ini adalah buktinya yaitu sebuah kitab monumental karya Imam al-Ghazali yang sangat terkenal dan telah banyak dibaca oleh berbagai kalangan. Oleh ulama-ulama fuqaha, Ihya dijadikan sebagai rujukan standar dalam bidang fiqih, sedangkan oleh para sufi, kitab ini memuat materi-materi pokok yang tidak boleh ditinggalkan. Kedua bahagian ilmu tersebut (fiqih dan tasawuf) memang terkandung di dalam kitab ini, sehingga menjadikan Ihya sebagai kitab yang sangat hebat, karena di dalamnya telah terangkum berbagai jenis ilmu.

${ }^{17}$ Dalam sebuah penelitian bahwa kitab Ayyuhal Walad sendiri ternyata memiliki 23 prinsip pendidikan karakter yang kesemuanya sesuai dengan konsep pendidikan saat ini. Lihat Agus Setiawan, Prinsip Pendidikan Karakter dalam Islam (Studi Komparasi Pemikiran al-Ghazali dan Burhanuddin al-Zarnuji), Dinamika Ilmu, 14 (1), 2014, h. 10.

${ }^{18}$ M. Bahri Ghazali, Konsep Ilmu Menurut Al-Ghazali, (Yogyakarta: CV. Pedoman Ilmu Jaya, 1991), h. 70.

Jurnal Ilmiah Al QALAM, Vol. 12, No. 1, Januari-Juni 2018 
Agus Setiawan: Reorientasi Keutamaan Ilmu Dalam Pendidikan Perspektif Al-Ghazali Pada Kitab Ihya 'Ulumuddin

Awalnya penyalinan kitab dilakukan dengan cara tulisan tangan (makhtutoh) yakni al-Ihya dibuat sebanyak hampir 120 makhtutoh yang kemudian di simpan di perpustakaan-perpustakaan terkenal di dunia, seperti perpustakaan darul Kutub al-Misriyyah, al-Azhar, Paris, Istanbul, Teheran, dan lainnya. Setelah era ditemukannya mesin percetakan, cetakan Ihya terus dilakukan dan diperbanyak, sehingga menjadi tersebar ke berbagai negara Muslim.

Secara global, isi keseluruhan kitab Ihya 'Ulumuddin telah mencakup tiga sendi utama pengetahuan Islam, yakni Syari`at, Thariqat, dan Haqiqat. Al-Ghazali juga telah mengkoneksikan ketiganya dengan praktis dan mudah ditangkap oleh nalar pembaca. As-Sayyid Abdullah alAydrus memberikan sebuah kesimpulan bahwa dengan memahami kitab Ihya, seseorang telah cukup untuk meraih tiga sendi agama Islam tersebut.

Imam Zainuddin al-Iraqi berkata: "Kitab Ihya 'Ulumuddin adalah termasuk kitab Islam paling agung dalam mengetahui halal dan haram, menghimpun hukum hakam zahir, dan mencabutnya kepada rahasia-rahasia yang sangat dalam pemahamannya. Tidak cukup hanya masalah furu' dan persoalannya, dan tidak pula membiarkan mengarungi lebih dalam ke dasar samudera sehingga tidak mampu kembali ke tepian, akan tetapi beliau mengumpulkan antara ilmu zahir dan ilmu bathin, menghiasai maknamaknanya dengan sebaik-baik tempatnya. Menuturkan mutiara-mutiara lafaz dan dhabtnya." 19

\section{Konsep Ilmu Pengetahuan dan Urgensinya}

Ilmu merupakan simbol kemajuan dan kejayaan suatu bangsa. Dalam sebuah artikel jurnal mengemukakan bahwa pembangunan dan kemajuan manusia adalah terkait dengan tapap dan penguasaan ilmu

\footnotetext{
${ }^{19}$ Imam Jalaaluddin Abdur Rahman as-Suyuti, Ta'rif al-Ahya bi Fadhail al-Ihya, Terjemah Inggris, The Dead Become Alive by the Graceof Ahlul Bayt, Muhammad Sa'id Hunafa Qadri, Ttp, h. 9.
}

Jurnal Ilmiah Al QALAM, Vol. 12, No. 1, Januari-Juni 2018 
Agus Setiawan: Reorientasi Keutamaan Ilmu Dalam Pendidikan Perspektif Al-Ghazali Pada Kitab Ihya 'Ulumuddin

pengetahuan dalam kalangan masyarakat. ${ }^{20}$ Islam dalam hal ini merupakan agama yang punya perhatian besar kepada ilmu pengetahuan. Islam sangat menekankan umatnya untuk terus menuntut ilmu.

Dari kondisi potensi menjadi wujud aktualisasi terdapat rentangan proses yang mengundang pendidikan untuk berperan memberikan jasanya maksudnya adanya ilmu sebagai perantara menjadikan manusia ${ }^{21}$ sehingga memiliki potensi, sehingga menurut pemakalah bahwa manusia menjadi berbeda dengan makhluk lain adalah pada penggunaan akalnya untuk berfikir.

Ada beberapa istilah yang dipakai untuk menyebutkan ilmu pengetahuan, seperti istilah ilmu, pengetahuan, al'ilm dan sains. ${ }^{22}$ Dalam konteks Islam istilah al'ilm didefisitkan sebagai pengetahuan, sedangkan sains itu tidak menghasilkan kebenaran absolut. Lebih jauh bahwa Ilmu adalah isim masdar dari 'alima yang berarti mengetahui, mengenal, merasakan, dan menyakini. Secara istilah, ilmu ialah dihasilkannya gambaran atau bentuk sesuatu dalam akal. Kata ilmu dengan berbagai bentuknya terulang 854 kali dalam al-Qur'an, dan digunakan dalam arti proses pencapaian pengetahuan dan obyek pengetahuan. Ilmu dari segi bahasa berarti kejelasan, karena itu segala yang terbentuk dari akar katanya

\footnotetext{
${ }^{20}$ Adibah Sulaiman, dkk, Konsep Ilmu menurut Perpsektif Syed Sheikh Ahmad al-Hadi, Jurnal Islamiyyat, 38, (2), 2016, h. 93.

${ }^{21}$ Dalam Ihya 'Ulumuddin, al-Ghazali yang dikutip oleh Abidin Ibnu Rusn menggunakan empat istilah untuk memaknai esensi dari manusia tersebut yaitu: qalb, ruh, nafs dan aql. Lebih lanjut menjelaskan bahwa manusia dapat memperoleh derajat atau kedudukan yang paling terhormat dimuka bumi ini tentunya dengan ilmu dan implikasinya/amalnya. Lihat Abidin Ibnu Rusn, Pemikiran Al-Ghazali tentang Pendidikan, (Yogyakarta: Pustaka Pelajar, 1998), h. 31, juga diterangkan oleh para filosof modern bahwa adalah makhluk rasional, artinya makhluk yang berfikir, lihat Fatchul Mu'in, Pendidikan Karakter Konstruksi Teoritik dan Praktik, (Yogyakarta: ArrRuz Media, 2011), h. 156. 104.

${ }^{22}$ Mujamil Qomar, Epistemologi Pendidikan Islam, (Jakarta: Erlangga, 2005), h.
}

Jurnal Ilmiah Al QALAM, Vol. 12, No. 1, Januari-Juni 2018 
Agus Setiawan: Reorientasi Keutamaan Ilmu Dalam Pendidikan Perspektif Al-Ghazali Pada Kitab Ihya 'Ulumuddin

mempunyai ciri kejelasan. Jadi dalam batasan ini faktor kejelasan merupakan bagian penting dari ilmu. ${ }^{23}$

Dari segi maknanya, pengertian ilmu sepanjang terbaca dalam pustaka menunjuk sekurang-kurangnya pada tiga hal, yakni pengetahuan, aktivitas, dan metode. Diantara para filosof dari berbagai aliran terdapat pemahaman umum bahwa ilmu adalah suatu kumpulan yang sistematis dari pengetahuan. ${ }^{24}$ Jadi pada umumnya ilmu diartikan sebagai sejenis dengan pengetahuan, akan tetapi tidak semua pengetahuan dapat diartikan sebagai ilmu. Karena mungkin saja pengetahuan tersebut tidak berdasarkan pada metode ilmiah.

Mengenai ilmu al-Ghazali membagi ilmu pengetahuan menjadi tiga kelompok, yakni ilmu yang tercela, ilmu yang terpuji, dan ilmu yang terpuji pada taraf tertentu. Sementara dari segi kepentingannya, al-Ghazali membagi ilmu menjadi 2, yakni ilmu yang wajib/fardhu (ilmu agama, ilmu yang bersumber dari kitabullah) dan ilmu yang fardhu kifayah (seperti ilmu hitung, ilmu kedokteran, ilmu teknik, ilmu pertanian, dll). ${ }^{25}$

Al-Ghazali mengusulkan beberapa ilmu pengetahuan yang harus dipelajari di sekolah,yaitu:

1. IlmuAlqurandan ilmu agama seperti fiqih, hadis, dan tafsir

2. Sekumpulan bahasa, nahwu dan makhraj serta lafadz-lafadznya, karena ilmu ini berfungsi membantu ilmu agama

3. Ilmu-ilmu yang fardhu kifayah, yaitu ilmu kedokteran, matematika, teknologi yang beraneka macam jenisnya, termasuk juga ilmu politik

4. Ilmu kebudayaan, seperti syair, sejarah, dan beberapa cabang filsafat. $^{26}$

${ }^{23}$ Imam Syafi'ie, Konsep Ilmu Pengetahuan dalam Al-Qur'an, (Yogyakarta: UII Press, 2000), h. 27.

${ }^{24}$ Imam Syafi'ie, Konsep..., h. 26.

${ }^{25}$ Abudin Nata, Filsafat Pendidikan Islam, (Jakarta: Logos Wacana Ilmu, 1997,)h. 166-167.

${ }^{26}$ Abudin Nata, Filsafat..., h. 167.

Jurnal Ilmiah Al QALAM, Vol. 12, No. 1, Januari-Juni 2018 
Agus Setiawan: Reorientasi Keutamaan Ilmu Dalam Pendidikan Perspektif Al-Ghazali Pada Kitab Ihya 'Ulumuddin

Peranan ilmu pengetahuan dalam kehidupan seseorang sangat besar, dengan ilmu pengetahuan, derajat manusia akan berbeda antara yang satu dengan yang lainnya. Sehingga tidaklah sama antara orang yang berpengetahuan dan orang yang tidak berpengetahuan.

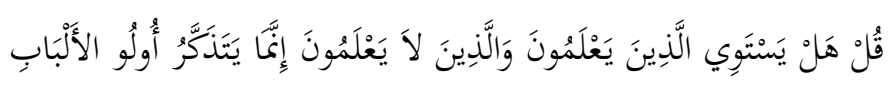

Artinya : "Katakanlah :"Adakah sama orang-orang yang mengetahui dengan orang-orang yang tidak mengetahui?" Sesungguhnya orang-orang yang berakallah yang dapat menerima pelajaran." (Az-Zumar:9 $)^{27}$

Allah SWT juga berfirman:

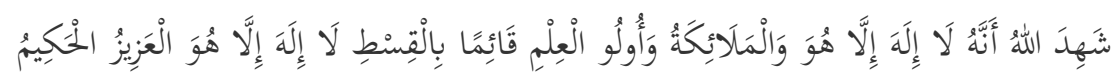

Artinya: "Allah menyatakan bahwasanya tidak ada Tuhan melainkan Dia (yang berhak disembah), yang menegakkan keadilan. para malaikat dan orang-orang yang berilmu (juga menyatakan yang demikian itu). tak ada Tuhan melainkan Dia (yang berhak disembah), yang Maha Perkasa lagi Maha Bijaksana” (QS. Ali Imran: 18$){ }^{28}$

Dalam ayat ini dijelaskan bahwa yang menyatakan tiada yang berhak disembah selain Allah adalah dzat Allah sendiri, lalu para malaikat dan para ahli ilmu. Diletakkannya para ahli ilmu pada urutan ke-3 adalah sebuah pengakuan Allah SWT, atas kemualian dan keutamaan para mereka.

${ }^{27}$ Departemen Agama RI, Al-Qur'an dan Terjemahnya, (Jakarta: CV. Naladana, 2004), h. 687.

${ }^{28}$ Departemen Agama RI, Al-Qur'an..., h. 145.

Jurnal Ilmiah Al QALAM, Vol. 12, No. 1, Januari-Juni 2018 
Agus Setiawan: Reorientasi Keutamaan Ilmu Dalam Pendidikan Perspektif Al-Ghazali Pada Kitab Ihya 'Ulumuddin

Dalam ayat lain Allah berfirman:

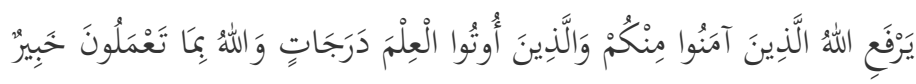

Artinya: "Niscaya Allah akan meninggikan orang-orang yang beriman di antaramu dan orang-orang yang diberi ilmu pengetahuan beberapa derajat, dan Allah Maha mengetahui apa yang kamu kerjakan”. (QS. Al-Mujadilah: 11) ${ }^{29}$

Berkata Ibnu 'Abbas dalam kitab Ihya 'Ulumuddin ketika menafsirkan ayat ini mengatakan bahwa derajat para ahli ilmu dan orang mukmin yang lain sejauh 700 derajat. Satu derajat sejauh perjalanan 500 tahun. $^{30}$

\section{Keutamaan Ilmu Perspektif Al-Ghazali dalam Ihya 'Ulumuddin}

Al-Ghazali dalam kitab Ihya 'Ulumuddin, memulai pandangannya dengan nada provokatif tentang keutamaan bagi mereka yang memiliki ilmu pengetahuan dengan mengutip Alquransurat al-Mujadilah ayat 11, yang artinya: "Allah akan meninggikan orang-orang yang beriman di antaramu dan orang-orang yang diberi ilmu pengetahuan beberapa derajat”. (QS. Al-Mujadilah:11)

Provokasi ini kemudian dilanjutkannya dengan hadis Nabi yang bernada majaz metaforik yang dikemukakan oleh Ibnu Abbas tentang keutamaan ilmuwan atas orang awam, pernyataan tersebut adalah: Li al'ulama' darajah fauqo al-mu'minina bisab'i mi'ah darajah ma bayna aldarajataini masirah khamsah mi'ah 'am. ${ }^{32}$

${ }^{29}$ Departemen Agama RI, Al-Qur'an..., h. 793.

${ }^{30}$ Al-Ghazali, Ihya 'Ulumuddin, Jilid 1, (Bairut: Darul Kutub al-Ilmiyah, 1970), h. 6, lihat juga Imam Al-Ghazali, IhyaUlumuddin, Jilid 1 Bab Keutamaan Ilmu, terjemahan, (Semarang: As Syifa', 1979), h. 5.

${ }^{31}$ Departemen Agama RI, Al-Qur'an..., h. 793.

${ }^{32}$ Lihat Al-Ghazali, Ihya..., h. 5.

Jurnal Ilmiah Al QALAM, Vol. 12, No. 1, Januari-Juni 2018 
Agus Setiawan: Reorientasi Keutamaan Ilmu Dalam Pendidikan Perspektif Al-Ghazali Pada Kitab Ihya 'Ulumuddin

Artinya "Para orang-orang yang berilmu memiliki derajat diatas orang-orang mukmin sebanyak tujuh ratus derajat, jarak di antara dua derajat tersebut adalah perjalanan lima ratus tahun".

Konsep pemikiran al-Ghazali tentang pendidikan lebih cenderung bersifat empirisme, hal ini disebabkan karena ia sangat menekankan pada pengaruh pendidikan terhadap anak didik. Menurutnya, pendidikan seorang anak sangat tergantung kepada orang tua yang mendidiknya. Lebih lanjut, dapat dikatakan bahwa dalam peranannya, pendidikan sangat menentukan kehidupan suatu bangsa dan pemikirannya.

Dengan melihat dan memahami beberapa karyanya yang berkaitan dengan pendidikan, dapat dikatakan bahwa al-Ghazali adalah penganut asas kesetaraan dalam dunia pendidikan, ia tidak membedakan kelamin penuntut ilmu, juga tidak pula dari golongan mana ia berada, selama dia islam maka hukumnya wajib, tidak terkecuali bagi siapapun. Dapat dikatakan pula, bahwa ia adalah penganut konsep pendidikan tabula rasa (kertas putih), dimana pendidikanlah yang bisa mewarnai seorang anak yang bagai kertas putih tersebut dengan hal-hal yang benar. Hal tersebut tercermin dalam salah satu kitabnya, Ihya 'Ulumuddin yang mengatakan bahwa seorang anak ketika lahir masih dalam keadaan fitrah (suci).

\section{E. Relevansi Keutamaan Ilmu Perspektif Al-Ghazali dalam Dunia Pendidikan Sekarang}

Begitu banyak problem pendidikan yang terjadi di Indonesia salah satunya adalah masih ada sebagian masyarakat yang tidak mengerti ilmu/bodoh, sehingga sangat tepat sekali bahwa sistem yang ada dalam dunia pendidikan harus dikembalikan pada konsep yang benar menurut konsep pendidikan Islam.

Saat ini Negara-negara Asia yang sangat sungguh-sungguh menghargai ilmu pengetahuan terbukti sekarang menjadi negara maju seperti Jepang, Korea dan Taiwan, disusul kemudian Singapura dan

Jurnal Ilmiah Al QALAM, Vol. 12, No. 1, Januari-Juni 2018 
Agus Setiawan: Reorientasi Keutamaan Ilmu Dalam Pendidikan Perspektif Al-Ghazali Pada Kitab Ihya 'Ulumuddin

Malaysia. Cina dan India yang sangat getol mendidik generasi mudanya untuk mengembangkan ilmu pengetahuan diperkirakan akan menjadi kekuatan ekonomi kedua setelah Amerika pada tahun 2015, disusul kemudian India pada tahun $2020 .^{33}$

Sesungguhnya konsep dan ajaran Islam selalu memotivasi umatnya untuk maju dan beradab. Seperti ajarannya tentang kewajiban menuntut ilmu dan menjunjung tinggi ilmu pengetahuan.

Kajian mengenai ilmu dalam perspektif al-Ghazali apabila dikaitkan dengan pendidikan sekarang tentu sangat tepat. Orang yang berilmu terlebih ilmu agama saat ini sangat diperlukan, namun tentunya berilmu karena Allah. Dalam kitab Ihya 'Ulumuddin, dikatakan bahwa manusia memahami betapa berartinya nikmat yang Allah s.w.t. berikan berupa ilmu, Dia ajarkan kepada manusia setelah dia ciptakan. Demikian penjelasan di seputar ketinggian dan keutamaan ilmu yang terangkum dalam firman-firmanNya. ${ }^{34}$

Adapun kelebihan dan kemuliaan ilmu yang terangkum dalam sabda Nabi s.a.w. dapat kami sebutkan rangkaiannya berikut ini. Rasulullah s.a.w. pernah bersabda:

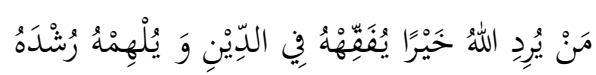

Artinya: "Siapa saja yang Allah kehendaki kebaikan ada pada dirinya, maka Dia anugerahkan kepada hamba tersebut ilmu (pemahaman) dalam urusan agama, serta diilhamkan-Nya kepada hamba itu petunjuk yang bisa ia ikuti. ,35

\footnotetext{
${ }^{33}$ Tobroni, Pendidikan Islam Paradigma Teologis, Filosofis dan Spiritualitas, (Malang: UMM Press. 2008), h. 38.

${ }^{34}$ Al-Ghazali, Ihya..., h. 6.

${ }^{35}$ Hadis dengan redaksi ini diriwayatkan oleh Muttafaqun 'alaih (Imam Bukhari dan Imam Muslim) dari jalur Mu'awiyah tanpa menggunakan redaksi Tambahan redaksi ini bersumber dari riwayat yang disampaikan oleh Imam ath-Thabrani dalam kitab Takbir, lihat Al-Ghazali, Ihya..., h. 6.
}

Jurnal Ilmiah Al QALAM, Vol. 12, No. 1, Januari-Juni 2018 
Agus Setiawan: Reorientasi Keutamaan Ilmu Dalam Pendidikan Perspektif Al-Ghazali Pada Kitab Ihya 'Ulumuddin

Rasulullah s.a.w. juga pernah bersabda:

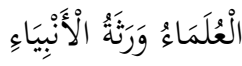

"Ulama (orang yang memiliki ilmu agama) itu adalah pewaris para Nabi. ${ }^{, 36}$

Seperti diketahui secara umum, bahwa tidak terdapat derajat kemanusiaan yang melebihi kedudukan para Nabi. Juga tidak tersedia kemuliaan hidup yang melebihi kemuliaan tugas kerasulan, sebagaimana yang diwariskan. ${ }^{37}$

Sesuai dengan fungsinya pendidikan di Indonesia merupakan sistem penyelenggaraan pendidikan oleh Negara, dalam rangka mewujudkan hak menentukan eksistensi nasional bangsanya dalam bidang pendidikan. Sedangan menurut strukturnya pendidikan nasional sebagai sistem adalah keseluruhan satuan kegiatan pendidikan yang direncanakan, dilaksanakan, dan dikendalikan dalam rangka menunjang tercapainya tujuan nasional suatu negara. ${ }^{38}$

Dasar empiris al-Ghazali membentuk kekhasannya dalam pengembangan ilmu-ilmu keislaman untuk lebih memilih keutamaan filosofis yang dipahaminya menjelaskan dan mendukung keutamaan religius. Al-Ghazali sebenarnya hendak menegaskan tersedianya ruang kosong untuk program ilmu keislaman dalam perkembangan pengetahuan ilmiah. Karenanya, pengembangan dan pelestarian ilmu keislaman adalah mungkin sering pengembangan ilmu pengetahuan dan teknologi.

Pengembangan dan pelestarian ilmu keislaman ini pada zamannya sangat berarti dalam mempertahankan kekhasan ilmu-ilmu keislaman, yaitu

\footnotetext{
${ }^{36}$ Hadis ini diriwayatkan oleh Abu Dawud, at-Tirmidzi, Ibnu Majah dan Ibnu
} Hibban dalam kitab Shậ̄h miliknya, dari jalur Abud-Darda', lihat Al-Ghazali, Ihya..., h. 6 .

${ }^{37}$ Al-Ghazali, Ihya..., h. 6.

${ }^{38}$ Suparian Suhartono, Kawasan Pendidikan,(Jogjakarta: Ar Ruzz Media, 2008.), h. 108 .

Jurnal Ilmiah Al QALAM, Vol. 12, No. 1, Januari-Juni 2018 
Agus Setiawan: Reorientasi Keutamaan Ilmu Dalam Pendidikan Perspektif Al-Ghazali Pada Kitab Ihya 'Ulumuddin

al-ulum al-syar'iyyah atau ulum naqliyah dan ulum aqliyyah atau ghair syar'iyyah.

Dalam pengembangan dan pelestarian ilmu keislaman di Indonesia, yang kita butuhkan adalah bagaimana melestarikan bangunan epistemologis ulama abad pertengahan dan sekaligus membangun kematangan epistemologi peserta program ilmu keislaman untuk menjawab problem umat manusia, seperti problem kekeliruan mental, kekeliruan intelektual, kekeliruan rasio, paradigma-paradigma yang mengaburkan, dunia yang tak terduga, pengetahuan yang tidak pasti, spesialisasi tertutup, rasionalitas palsu, hilangnya aspek-aspek manusiawi dalam manusia, ketidakpastian sejarah, ketidakpastian realitas, ketidakpastian dalam pengetahuan, dan pemikiran reduktif. Teori empiris al-Ghazali memiliki keunggulan dalam melahirkan kekhasan ilmu-ilmu keislaman, yang relevan untuk pengembangan dan pelestarian ilmu keislaman di Indonesia.

Perspektif pemikiran al-Ghazali, kajian keutamaan ilmudalam konteks sekarang dapat diarahkan pada beberapa hal berikut:

1. Sejauh manfaat yang diberikan kepada manusia dalam kehidupan keagamaan dan kehidupan akhirat, berupa penyentuhan jiwa, perbaikan akhlak, pendekatan diri kepada Allah dan persiapan untuk abadi.

2. Sejauh manfaat yang diberikan kepada manusia dari segi kebutuhan dan dukungan yang diberikan untuk ilmu agama.

3. Sejauh manfaatnya bagi kehidupan manusia.

4. Sejauh manfaat yang diberikan dalam kebudayaan, kesejahteraan manusia serta keterlibatan pada kehidupan kemasyarakatan.

Dasar ilmu keislaman dalam perspektif al-Ghazali adalah adanya keterkaitan antara teori empirisme, keutamaan filosofis dan keutamaan religius. Untuk mengoperasionalkan empirismenya, al-Ghazali tidak hanya mengkaji persoalan-persoalan pengetahuan manusia, tetapi juga mengkaji dasar-dasar filsafat Yunani, perkembangan pemikiran ulama abad

Jurnal Ilmiah Al QALAM, Vol. 12, No. 1, Januari-Juni 2018 
Agus Setiawan: Reorientasi Keutamaan Ilmu Dalam Pendidikan Perspektif Al-Ghazali Pada Kitab Ihya 'Ulumuddin

pertengahan (al-Farabi, Ibn Sina) dan mengkaji pokok-pokok teks Alqurandan hadits.

Dengan demikian menurut pemakalah sangatlah komplit apa yang ada pada kitab Ihya 'Ulumuddin tepatnya pada bab awal yaitu fadilah/keutamaan ilmu kalau dikaitkan dengan pendidikan masa sekarang. Fenomena sekarang banyak yang sudah melenceng daripada penerapaan atau aplikasi ilmu tersebut sehingga belum tentu orang yang berilmu mempunyai adab atau etika dalam kehidupannya, hal ini disebabkan karena niat menuntut ilmu tersebut yang diselewengkan. Saat ini, pendidikan Islam yang dibutuhkan adalah memurnikan kembali niat kita untuk menuntut ilmu karena Allah sehingga, ketika aplikasinya di lapangan dimana kita berada dapat berguna bagi diri, keluarga maupun masyarakat dan negara juga bangsa. Ilmu yang pada hakikatnya murni tentunya akan kembali murni bagi para penuntut ilmu sehingga menjadi berkah, karena ilmu pada hakikatnya membawa keberkahan baik di dunia maupun di akhirat.

\section{F. Simpulan}

Al-Ghazali yang lahir di Ghazalah, di kota Thus termasuk daerah Khusaran Iran pada tahun 450 H/1058 M. Sekitar 55 tahun beliau berkecimpung dalam berbagai bidang pada masa itu. Tidak hanya sebagai seorang yang ahli dalam ilmu agama, seorang al-Ghazali merupakan tokoh yang multitalenta. Sebagai filosof, 'ulama juga sufi, sehingga lengkap sudah perjalanan hidup al-Ghazali dalam mengarungi kehidupan. Karyanya begitu dikenal sampai 300 lebih sehingga dalam beberapa abad kedepan akan terus dikaji secara mendalam terhadap apa yang telah ditinggalnya dalam sebuah karya-karya dan buku, begitu pula kitab Ihya 'Ulumuddin.

Kitab Ihya 'Ulumuddin hadir dengan sangat fenomena di zamannya dan masih fenomena hingga saat ini walaupun ada juga yang mengkritik. Ini

Jurnal Ilmiah Al QALAM, Vol. 12, No. 1, Januari-Juni 2018 
Agus Setiawan: Reorientasi Keutamaan Ilmu Dalam Pendidikan Perspektif Al-Ghazali Pada Kitab Ihya 'Ulumuddin

juga menjadi bukti dengan masih diteliti dan dijadikannya kitab Ihya 'Ulumuddin baik di kalangan akademisi maupun kalangan pesantren sebagai objek yang menarik dikaji ulang. Karya ini merupakan hadiah yang sangat istimewa dari al-Ghazali sebagai panduan hidup umat Islam dalam meraih kebahagiaan hidup di dunia dan di akhirat. Begitu banyak pesan diberikan al-Ghazali dalam buku tersebut yang berlandaskan dalil baik dari Alquran maupun Hadits.

Sebagai kitab yang banyak dikaji ulang, maka di dalamnya ditemukan suatu konsep ilmu pengetahuan. Ilmu pengetahuan kemudian berkembang sesuai dengan pandangan al-Ghazali sehingga menjadi khas. Ilmu pengetahuan juga mempunyai peran dalam kehidupan seseorang sangat besar, dengan ilmu pengetahuan, derajat manusia akan berbeda antara yang satu dengan yang lainnya. Sehingga tidaklah sama antara orang yang berpengetahuan dan orang yang tidak berpengetahuan.

Dalam kitab Ihya 'Ulumuddin, al-Ghazali memulai pandangannya dengan nada provokatif tentang keutamaan bagi mereka yang memiliki ilmu pengetahuan dengan mengutip Alquran surat al-Mujadilah ayat 11 . Provokasi ini kemudian dilanjutkannya dengan hadis Nabi yang bernada majaz metaforik yang dikemukakan oleh Ibnu Abbas tentang keutamaan ilmuwan atas orang awam, pernyataan tersebut adalah:Li al-'ulama' darajah fauqo al-mu'minina bisab’i mi'ah darajah ma bayna aldarajataini masirah khamsah mi'ah 'am.

Begitu banyak problem pendidikan yang terjadi di Indonesia sehingga sangat tepat sekali bahwa sistem yang ada dalam dunia pendidikan harus dikembalikan pada konsep yang benar menurut konsep pendidikan Islam. Kajian mengenai ilmu dalam perspektif al-Ghazali apabila dikaitkan dengan pendidikan sekarang tentu sangat tepat. Penjelasan al-Ghazali mengenai ilmu meluas menjadi dasar empiris dalam pengembangan berikutnya. Intinya adalah relevansi yang ada pada kitab Ihya 'Ulumuddin menurut pemakalah sangatlah tepat saat ini, kembali memurnikan ilmu

Jurnal Ilmiah Al QALAM, Vol. 12, No. 1, Januari-Juni 2018 
Agus Setiawan: Reorientasi Keutamaan Ilmu Dalam Pendidikan Perspektif Al-Ghazali Pada Kitab Ihya 'Ulumuddin

tersebut, ilmu yang didapat harus diniatkan karena Allah dan kemudian di amalkan pada dunia pendidikan karena Allah.

\section{G. Rekomendasi}

Kitab Ihya 'Ulumuddin bmenurut pemakalah patut untuk dijadikan kajian sepanjang zaman dan terlebih pada konteks sekarang ini. Ada beberapa hal yang perlu dikembangkan dalam bidang keilmuan sehingga menjadi konsep yang utuh untuk diaplikasikan pada sebuah bagian sistem pendidikan. Konsep ilmu yang dikembangkan hendaknya dijadikan standar peningkatan mutu pendidikan terlebih pendidikan Islam. Jangan ada lagi masyarakat yang tidak berilmu atau tidak sekolah. Sehingga apa yang dicita-citakan bangsa menjadikan manusia Indonesia seutuhnya yang memiliki ilmu akan tercipta. 
Agus Setiawan: Reorientasi Keutamaan Ilmu Dalam Pendidikan Perspektif Al-Ghazali Pada Kitab Ihya 'Ulumuddin

\section{Daftar Pustaka}

Al-Ghazali, Ihya 'Ulumuddin, Jilid 1, Bairut: Darul Kutub al-Ilmiyah, 1970.

Al-Ghazali, Ihya Ulumuddin, Jilid 1 Bab Keutamaan Ilmu, terjemahan, Semarang: As Syifa', 1979.

Al-Jauziyah, Ibnu Qayyim.Al'Ilmu (Buah Ilmu), Terj. Fadhil Bahri, Jakarta: Pustaka Azzam, 2000.

An-Nawawi, Majmu’ Syarah al Muhadzdzab, Maktabah Syamilah, Juz 1.

Departemen Agama RI, Al-Qur'an dan Terjemahnya, Jakarta: CV. Naladana, 2004.

Ghazali, M. Bahri. Konsep Ilmu Menurut Al-Ghazali, Yogyakarta: CV. Pedoman Ilmu Jaya, 1991.

Marzuki, dkk, dalam Wacana Jurnal Studi Islam, Surabaya: IAIN Sunan Ampel, 2005.

Mu'in, Fatchul, Pendidikan Karakter Konstruksi Teoritik dan Praktik, Yogyakarta: Arr-Ruz Media, 2011.

Munawir, Imam. Mengenal Pribadi 30 Pendekar dan Pemikir Islam dari Masa Ke Masa, Surabaya: PT. Bina Ilmu Offset, 2006.

Nata, Abuddin. Filsafat Pendidikan Islam, Jakarta: Logos Wacana Ilmu, 1997.

Othman, Ali Issa. Manusia Menurut Al-Ghazali, Bandung: Pustaka, 1987.

Qomar, Mujamil. Epistemologi Pendidikan Islam, Jakarta: Erlangga, 2005.

Rusn, Abidin Ibnu, Pemikiran Al-Ghazali tentang Pendidikan, Yogyakarta: Pustaka Pelajar, 1998.

Safroni, M. Ladzi. Al-Ghazali Berbicara tentang Pendidikan Islam, Malang: Aditya Media Publishing, 2013.

Setiawan, Agus. Prinsip Pendidikan Karakter dalam Islam (Studi Komparasi Pemikiran al-Ghazali dan Burhanuddin alZarnuji), Dinamika Ilmu, 14 (1), 2014.

Sholeh, Asrorun Ni'am. Reorientasi Pendidikan Islam Mengurai Relevansi Konsep Al-Ghazali dalam Kontek Kekinian, Jakarta: eLSAS, 2004.

Jurnal Ilmiah Al QALAM, Vol. 12, No. 1, Januari-Juni 2018 
Agus Setiawan: Reorientasi Keutamaan Ilmu Dalam Pendidikan Perspektif Al-Ghazali Pada Kitab Ihya 'Ulumuddin

Suhartono, Suparian. Kawasan Pendidikan, Jogjakarta: Ar Ruzz Media, 2008.

Sulaiman Adibah, dkk, Konsep Ilmu menurut Perpsektif Syed Sheikh Ahmad al-Hadi, Jurnal Islamiyyat, 38, (2), 2016.

Syafi'ie, Imam. Konsep Ilmu Pengetahuan dalam Al-Qur'an, Yogyakarta: UII Press, 2000.

Syukur, M. Amin. Studi Akhlak, Semarang: Walisongo Press, 2010.

Tim Dosen Fakultas Tarbiyah UIN Malang, Pendidikan Islam dari Paradigma Klasik Hingga Kontemporer. 